\section{RECENT JOURNAL ARTICLES}

Absorption: Fur l'absorption des gaz par le charbon aux basses températures. By G. GLAUDE. Bulletin de la Société Chimique de France.

Cellulose: Recent Progress in the Analysig of Cellulose and Cellulose Derivatives. By J. F. Briggs. The Analyst, Vol. 40, 1915, No, 468, pp. $107-20$.

Concrete: Basis of Current Practice in Concrete Design. By C. A. P. TURNer. The Cement Era, Vol. 13, 1915, No. 4, pp. 50-1.

Copper: Hydrometallurgical Treatment of Michigan Copper Tallings. By R. D. LEIsK. Metallurgical and Chemical Engineering, Vol. 13, 1915, No. 4, pp. 233-4.

Cyanide: Copper Cyanide Plating solutions. By M. C. WEBER. Metallurgical and Chemical Enginéering, Vol. 13, 1915, No. 4, pp. 255-6.

Flectrolysis: Electrolysis and Its Mitlgation. By E. B. Rosa. Journal of the New England Water Works Association. Vol. 29, 1915, No. 1, pp. 49-72.

Gas: Burning Blast Furnaco Gas. Anonymous. The Iron Age, Vo1. 95, 1915, No. 11, pp. 612-3.

Ice: The Economical Ice Plant of Today. By Thomas Shrley. Ice and Refrigerction, Vol. 48, 1915, No. 4, pp. 204-9.

Ice: Suggestions for the Improvement of Refrigerating and IceMaking Plants. By ROBERT P. KEHOE. Refrigeraling, World, Vol. 49, 1915, No. 2, pp. 27-9.

Inorganic Chemistry: Experimentelle anorganische Chemie und Elektrochemie im Jahre 1914. By A. GUTBIER. Zeitschrift für angewandte Chemie, Vol. 28, 1915, No. 20, pp. 93-111.

Lighting: Street Lighting Practice with Incendescent Lamps. By G. H. STrckNey. Municipal Engineering, Vol. 48, 1915, No. 2 , pp. $80-8$.

Minerals: General Principles Governing the Complete Analysis of Minerals and Ores. By W. R. Schoelier. The Analyst, Vol. 40, 1915. No, 468, pp. 90-106.

Nitiogen: The Fixation of Atmospheric Nitrogen. By W. S. LANDIS. Metallurgical_and Chemical_Engineering, Vol. 13, 1915, No. 4, pp. 213-20.

Organic Compounds: The Flectrochemical Production of Organic CompoundB. ANonymous. Metallurgical and Chemical Engineering, Vol. 13, 1915, No. 4, pp. 211-13.

Ozone: The Use of Ozone as a sterilizing Agent for Water Purification. By S. T. PowelL. Journal of the New Englond Water Works Association, Vol. 29, 1915, No, 1, pp. 87-93.

Paving Material: Misuse of a Good Paving Material Is Detrimental to Florida Road Development. By Charles E. Foote. Engineering Record, Vo1. 71, 1915, No. 15, pp. 452-3.
Roads: Frost Action on Roads. By ANdrew M. Lovis, The Cement Era, Vol. 13, 1915, No. 3, pp. 49-50.

Refractories: Refractories of the Rocky Mountain Region and Some of Their Products. By J. C. BAILAR. Metallurgical and Chemical Engineering, Vol. 13, 1915, No. 4, pp. 257-8.

sanitation: The Federal Meat Inspection Service and Sanitation of Packing Houses under Its Supervision. By GEORGE H. SHAw. A merican Journal of Public Health, Vol. 5, 1915, No. 3, pp. 236-45.

Sewage: Sewage Aeration at Iawrence and Manchester Compared. By H. W. ClARK. Engineering Record, Vol. 71, 1915, No. 12, pp. 367-8. Sewage: The West End Sewage Treatment Works, Hamilton, Ont By Bernard E. T. Elis. Engineering News, Vol. 73, 1915, No. 9, pp. 424-8.

Steel: Acid Open-Hearth steel for Castings. By Edwin F. Cone. The Iron Age, Vol. 95, 1915, No. 10, pp. 551-3.

Steel: "Areagrams" of Open-Hearth Furnace Flues. By A. R, Mitcheli. The Iron Age, Vol. 95, 1915, No. 11, pp. 607-8.

Steel: Heat Energy from the Bessemer Process. By G. Burz. The Iron Age, Vol. 95, 1915, No. 11, pp. 618-9.

Steel: Hrsteresis Loss in Medium-Carbon Steel. By F. C. LANGENBERG AND R. G. WEBBER. The Iron Age, Vol. 95, 1915, No. 9, pp 506-8.

Sulfates: The Formation and Decomposition of sulfates during Roasting. By Boyd DudLey, JR. Metallurgical and Chemical Engineering, Vol. 13, 1915, No. 4, pp. 221-6.

Sulfuric Acid: Neuerungenbetreffend Bleikammern, Turmsjsteme und andere Vorrichtungen zur Herstellung von Schwefelsäure. By Oskar Kausch. Chemische Apparatur, Vol. 2, 1915 , No. 4 , pp. 53-5.

Turbines: Turbine Effleiency Test by Chemical Mothods. ANonymous. Engineering Record, Vol. 71, 1915, No. 12, pp. 358-60.

Valence: A Criticism of the Electron Conception of Valence. By ROGER F. Bruner. Journal of the American Chemical Society, Vol. 37, 1915, No. 4, pp. 709-22.

Water: Philadelphia Water-Filter Operations in 1914. AnONyMous. Engineering News, Vol. 73, 1915, No. 12, pp. 576-7.

Wood: Die Imprägnierung des Holzes nach dem Verfahren des Dr. Boucherie. By FrIEDRICH MOLL. Chemische Apparatur, Vol. 2 , 1915, No. 4, pp. 49-53.

Zinc: Die Bestimmung des Zinks als Zinkammoniumphosphat und ihre Anwendung bei Trennungen. By P. ARTMANN. Zeitschrift fïr analytische Chemie, Vol. 54, 1915, No. 2, pp. 89-102.

Zinc: Leaching a Zinc-Lime Ore with Acids. By O. C. RALSToN and A. E. GARTsidE. Metallurgical and Chemical Engineering, Vol. 13, 1915. No. 3, pp. 151-5.

RECENT INVENTIONS

\section{UNITED STATES PATENTS}

BY C. L. PARKER

Solicitor of Chemical Patents, McGill Building, Washington, D. C.

Manufacturing Mixed Hydrogen and Nitrogen. G. P. Scholl, Jan. 5, I915. U. S. Pat. I,123,394. A mixture of nitrogen and hydrogen having definite proportions is produced by vaporizing ammonia, holding it under a given pressure, which

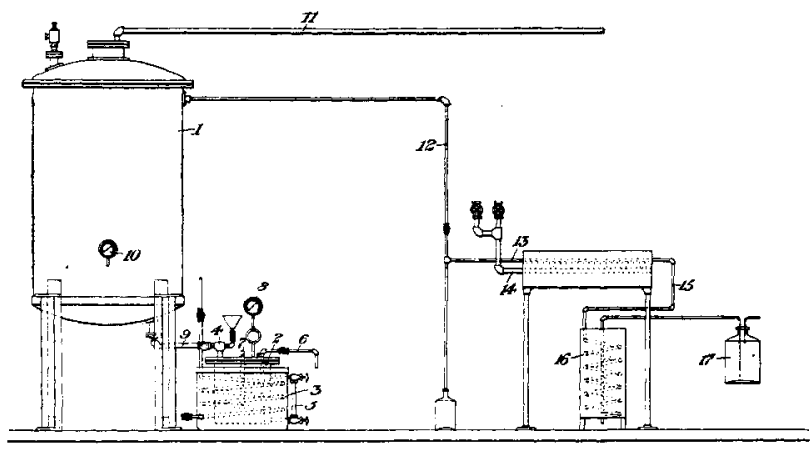

may be from 20 to 30 lbs. per sq. in., mixing with air and dissociating the ammonia at a predetermined pressure, which may be Io lbs. per sq. in., by passing the mixed gases over copper turnings heated to approximately $720^{\circ} \mathrm{C}$.

Preventing Accumulation of Moisture of Condensation upon Glass or Other Protected Surfaces. H. M. Pickering, Jan. 5, I9I5. U. S. Pat. I,I23,367. The composition consists of 20 parts of glycerin, 2 parts of oil of turpentine, and I part of oil of eucalyptus.

Fixing Atmospheric Nitrogen. S. Peacock, Jan. 5, r9r5. U. S. Pat. $1,123,584$. A compound of sulfur, carbon and nitrogen is produced by bringing a mixture containing nitrogen and an oxid of sulfur into contact with carbon at a temperature of $800^{\circ} \mathrm{C}$

Precipitant for Recovering Metals from Solutions. G. H. Clevenger, Jan. 5, 19I5. U. S. Pat. I, I23,685. The precipitant consists of a powder made from a brittle alloy composed of zinc and not more than 3 per cent sodium, the sodium being added to impart brittleness to the alloy.

Marine Protective Coating. D. F. Comstock, Jan. 5, I9I5. U. S. Pat. I, I23,687. The composition consists of a water-resisting copper paint and a small amount of a radioactive substance, preferably pulverulent carnotite.

Pigments. C. D. Holley, Jan. 5, I9I5. U. S. Pat. I,I23,743. Metallic lead is moistened with water containing a relatively small amount of nitric acid and the mass is allowed to undergo progressive spontaneous oxidation in the presence of air to form oxids of lead.

Alkali-Metal Compounds. H E. Brown, Jan. 5, I915. U. S. Pat. I,123,84 I. Potash is obtained from eldspar by fusing, in a non-reducing atmosphere, a mixture of feldspar with a sufficient quantity of potassium chloride to furnish combinable chlorine for all the potassium and a sufficient quantity of calcium carbonate to bring the calcium oxide content of the resulting fused material up to between 40 and 55 per cent. 